\title{
Tumor Protein p53-Inducible Nuclear Protein 1
}

National Cancer Institute

\section{Source}

National Cancer Institute. Tumor Protein p53-Inducible Nuclear Protein 1. NCI

Thesaurus. Code C92492.

Tumor protein p53-inducible nuclear protein 1 (240 aa, $\sim 27 \mathrm{kDa}$ ) is encoded by the human TP53INP1 gene. This protein plays a role in the mediation of apoptosis. 